\title{
ORIGINALS
}

\section{A Sensitive Double Antibody Radioimmunoassay for Human Growth Hormone (HGH): Levels of Serum HGH Following Rapid Tolbutamide Infusion*}

\author{
GUENTHer Boden** and J. Stuart Solldner
}

The Elliott P. Joslin Research Laboratory, Department of Medicine, Peter Bent Brigham Hospital, Harvard Medical School, and the Diabetes Foundation, Inc., Boston, Massachusetts, USA

Received January 18, 1967

Summary. A double antibody radio-immunoassay for human growth hormone is described. - The assay can detect $0.0625 \mathrm{~m} \mu \mathrm{g} \mathrm{HGH} / \mathrm{ml}$ serum and has good reproducibility. It was found that: 1. a highly pure labelled hormone; 2, a specific and very potent guinea pig antihuman growth hormone antibody; and 3. at least five days of incubation for the first reaction were necessary to achieve this accuracy and sensitivity. - Porcine and rat growth hormone, sera from cow, guinea pig, rabbit, mouse, and toad fish did not react with the guinea pig anti-HGH serum used in the assay. - In four patients after hypophysectomy, HGH concentrations disappeared almost completely, and in another patient no rise of the hormone was seen during an IV insulin tolerance test. Undiluted human serum appears to produce falsely high levels of HGH. - Normal males exhibited fasting $\mathrm{HGH}$ levels from $0-2.2 \mathrm{~m} \mu \mathrm{g} / \mathrm{ml}$ (mean $0.8 \mathrm{~m} \mu \mathrm{g} / \mathrm{ml}$ ). Females ranged from $0.6-15.0 \mathrm{~m} \mu \mathrm{g} / \mathrm{ml}$ (mean $5.1 \mathrm{~m} \mu \mathrm{g} / \mathrm{ml}$ ) and 15 acromegalics from $8.0-103.0 \mathrm{~m} \mu \mathrm{g} / \mathrm{ml}$ (mean $31.2 \mathrm{~m} \mu \mathrm{g} / \mathrm{ml}$ ). - During a rapid tolbutamide tolerance test, serum HGH rose between $2.5-$ and 82 - fold over the fasting levels within 10 to 70 minutes following the glucose nadir.

Un dosage radio-immunologique sensible, à deux anticorps, pour l'hormone de croissance humaine (HGH): Taux sériques de l'hormone de croissance humaine après injection intraveineuse de tolbutamide.

Résumé. Les auteurs décrivent un dosage radioimmunologique à deux anticorps, pour l'hormone de croissance humaine. - Le dosage peut détecter $0.0625 \mathrm{~m} \mu \mathrm{g}$ de $\mathrm{HGH} / \mathrm{ml}$ de sérum et a une bonne reproductibilité. On a trouvé que 1. une hormone marquée très pure, 2. un anticorps de cobaye anti-hormone de croissance humaine, spécifique et très puissant, et 3 . au moins cinq jours d'incubation pour la première réaction étaient nécessaires pour obtenir cette précision et cette sensibilité. L'hormone de croissance de porc et de rat, des sérums de vache, de cobaye, de lapin, de souris et de crapaud de mer ne réagissaient pas avec le sérum de cobaye anti-HGH, utilisé dans le dosage. - Chez quatre patients, les concentrations d'HGH disparaissaient presque complètement après hypophysectomie, et chez un autre patient on n'a constaté aucune augmentation de l'hormone pendant un test i. v. de tolérance à l'insuline. - Le sérum humain non dílué se révèle produire des taux d'HGH faussement élevés. - Les hommes normaux avaient à jeun des taux d'HGH de $0-2.2 \mathrm{~m} \mu \mathrm{g} / \mathrm{ml}$ (moyenne: $0.8 \mathrm{~m} \mu \mathrm{g} / \mathrm{ml}$ ). Les femmes avaient des taux de $0.6-15.0 \mathrm{~m} u \mathrm{~g} / \mathrm{ml}$ (moyenne: $5.1 \mathrm{~m} \mu \mathrm{g} / \mathrm{ml}$ ) et 15 acromégales avaient des taux de $8.0-$ $103.0 \mathrm{~m} \mu \mathrm{g} / \mathrm{ml}$ (moyenne: $31.2 \mathrm{~m} \mu \mathrm{g} / \mathrm{ml}$ ). - Pendant un test rapide de tolérance au tolbutamide, l'HGH sérique s'élevait de 2,5 fois à 82 fois au-dessus des niveaux à jeun, dans les 10 à 70 minutes après que le glucose ait atteint son niveau le plus bas.

Untersuchungen mit einer empfindlichen radioimmuno. logischen Doppelantikörpermethode für menschliches Wachs. tumshormon (HGH): Wachstumshormonspiegel im Serum nach rascher Infusion von Tolbutamid.

Zusammenfassung. Es wird eine radioimmunologische Doppelantikörpermethode für menschliches Wachstumshormon (HGH) beschrieben. - Die Reproduzierbarkeit der Ergebnisse war gut. Die geringste meßbare HGH. Konzentration war $0.0625 \mathrm{~m} \mu \mathrm{g} / \mathrm{ml}$ Serum. Es wurde gefunden, daß, um diese Genauigkeit und Empfindlichkeit zu erreichen, 1. ein hochgereinigtes markiertes Hormon, 2. ein spezifischer und sehr wirksamer Meerschweinchenanti-HGH-Antikörper und 3. mindestens fünf Tage Inkubation für die erste Reaktion nötig waren. Schweine- und Rattenwachstumshormon, Kuh-, Meerschweinchen-, Kaninchen-, Mäuse- und Fischseren (Opsanus tau) reagierten nicht mit dem Meerschweinchen antiHGH Serum, das in dieser Methode verwendet wurde. Bei vier Patienten verschwand HGH fast vollständig nach Hypophysectomie und bei einem anderen Patienten erfolgte kein Hormonanstieg während eines i.v. Insulin Toleranz Testes. - Die Verwendung von unverdiunntem menschlichen Serum führte bei der Messung von HGH zu fälschlich hohen Resultaten. - Männliche Normalpersonen hatten HGH Spiegel von $0-2.2 \mathrm{~m} \mu \mathrm{g} / \mathrm{ml}$ (Mittel: $0.8 \mathrm{~m} \mu \mathrm{g} / \mathrm{ml}$ ), Frauen hatten HGH Spiegel von $0.6-15.0 \mathrm{~m} \mu \mathrm{g} / \mathrm{ml}$ (Mittel: $5.1 \mathrm{~m} \mu \mathrm{g} / \mathrm{ml}$ ), und fünfzehn Patienten mit Acromegalie zeigten OGH Werte von 8.0$103.0 \mathrm{~m} \mu \mathrm{g} / \mathrm{ml}$ (Mittel: 31.2. $\mathrm{m} \mu \mathrm{g} / \mathrm{ml}$ ). - Während eines Tolbutamid Toleranz Testes stieg das Serum HGH auf das zweieinhalb bis zweiundachtzigfache des Nüchternwertes innerhalb von 10 bis 70 Minuten nach Erreichen des tiefsten Blutzuckerwertes.

Key-words: Equilibrium first and secound reaction, Recovery, Serum dilution, Degradation, Sensitivity, Reproducibility, Specificity, Range in normals and acromegalics, Intravenous tolbutamide test.
Since 1963, assay techniques for human growth hormone (HGH) $[4,6]$ based on the principles of the

* Supported by the U.S.P.H.S. grants DTG-AM-05077, AM-09748-02, and the John A. Hartford Foundation, New York, New York.

** Performed in part during a postdoctoral fellowship Stiftung Volkswagenwerk, Germany. insulin radioimmunoassay of YALOW and BERson [20] have been used successfully. A double antibody immunoassay has been reported by ScHaLcH and Parker [16], but this assay was only sensitive enough to measure HGH levels in serum higher than 2.5 $\mathrm{m} \mu \mathrm{g} / \mathrm{ml}$. This report describes a double antibody immunoassay for human growth hormone similar to 
an assay technique for insulin employed in this laboratory [17] and includes an evaluation of some of its critical components. This assay allows the measuring of a large number of serum samples in a given time and provides the same degree of sensitivity, specificity, and reproducibility as the chromatoelectrophoretic methods $[4,6]$.

The basis of the immunoassay is inhibition of the binding of a trace amount of radiolabelled HGH (HGH-I $\left.{ }^{131}\right)$ to guinea pig, anti-HGH serum by either serum HGH or crystalline HGH employed as standards.

Separation of bound from unbound HGH-I ${ }^{131}$ is then accomplished by precipitating the anti-HGH antibody bound HGH-I'131 with a rabbit, antiguinea pig globulin, serum [14]. The concentration of HGH in unknown samples can then be determined from a standard curve obtained with the known amounts of crystalline HGH.

\section{Materials}

1. Borate buffer with $0.1 \%$ crystalline bovine serum albumin $(8.25 \mathrm{~g}$ boric acid; $2.70 \mathrm{~g} \mathrm{NaOH}$; $1.0 \mathrm{~g}$ crystalline bovine serum albumin, Armour Pharmaceuticals; $0.1 \mathrm{~g}$ merthiolate, Eli Lilly Company) were dissolved with distilled water to $1000 \mathrm{ml}$ and adjusted to $\mathrm{pH} 8.0$ with $5 \mathrm{~N} \mathrm{HCl}$. This was used for all dilutions of serum, antiserum, and HGH-I'131.

2. Highly purified $\mathrm{HGH}^{1}$ was kindly supplied to us by Dr. A.E. Wrhelmi. It was dissolved in $1 \mathrm{~N}$ $\mathrm{HCl}$ at a concentration of $1 \mathrm{mg} / \mathrm{ml}$, divided in aliquots and kept frozen at $-20^{\circ} \mathrm{C}$. One aliquot was not used for a longer time than one month, since repeated thawing and freezing might damage the $\mathrm{HGH}$.

For each assay, dilutions were made from this stock solution and used for the standard curve. The concentrations of standards employed were 0.025 , $0.05,0.1,0.3,0.4,0.8$, and $1.6 \mathrm{~m} \mu \mathrm{g} / \mathrm{ml}$.

3. Guinea pig anti-HGH serum $(\mathrm{AB})$ was given to us by courtesy of Dr. M. GRumbach (San Francisco) and used in a dilution of $1: 600000$.

4. Normal guinea pig serum was obtained by cardiac puncture from normal guinea pigs and diluted $1: 400$.

5. Rabbit, anti-guinea pig globulin serum (RAGS) was purchased from Arnel Products, New York City, New York.

\section{Methods}

Iodination. HGH (HS 612B WILHELMI) was labelled with $I^{131}$ to a specific activity of $280-320$ $\mathrm{mc} / \mathrm{mg}$ using the method of HUNTER and GREENWOOD [9]. Five $\mu \mathrm{g}$ HGH in $0.03 \mathrm{ml}$ of phosphate buffer was reacted with $2 \mathrm{mc} \mathrm{Na} \mathrm{I}^{1312}$. After addition of a small

${ }^{1}$ Lot NIH-GH-HS $612 \mathrm{~B}$, growth activity $=1.7 \mathrm{IU} /$ $\mathrm{mg}$; prolactin activity $=9 \mathrm{IU} / \mathrm{mg}$.

2 Obtained as $\mathrm{Na}^{131}$ in NaOH from Isoserve, Cambridge, Massachusetts. amount of normal human serum $(0.05 \mathrm{ml})$ to bind damaged $\mathrm{HGH}$, the $\mathrm{HGH}-\mathrm{I}^{131}$ was separated from iodide and damaged HGH components by passage through a Sephadex G-50 (fine) column equilibrated in potassium phosphate buffer, 0.05 molar, $\mathrm{pH} 7.5$.

Eluates of $0.5 \mathrm{ml}$ were collected in $0.1 \mathrm{ml}$ of phosphate buffer containing $2 \%$ crystalline bovine serum albumin. All fractions were evaluated for $\mathrm{I}^{131}$ activity. Two peaks of radioactivity were seen. The first peak contained in the earlier fractions damaged components, and HGH-I ${ }^{131}$ in the later fractions; the second peak consisted of unreacted $\mathrm{Na} \mathrm{I}^{131}$. Several fractions from the first peak were tested for content of intact HGH-I ${ }^{131}$ utilizing hydrodynamic flow chromatography on Whatman $3 \mathrm{MM}$ paper in veronal buffer ( $\mathrm{pH} 8.6$, 0.075 ionic strength) [20].

Immunoassay procedure. Table 1 shows the order in which reagents were added and the volumes used. All standards and sera were assayed in duplicate. Fig. 1 shows a standard curve which was obtained using the above described technique.

Table 1. Reactants of the double antibody immunoassay for human growth hormone (HGH)

Standard HGH or dil. serum

HGH-I ${ }^{131}(0.05 \mathrm{~m} \mu \mathrm{g}$ or $0.025 \mathrm{~m} \mu \mathrm{g})$

Guinea pig anti- $H G H$ serum $(\mathrm{d}$
First incubation: 6 days at $4^{\circ} \mathrm{C}$

Normal guinea pig serum (dil. 1:400)

Rabbit antiguinea pio globulin serum (dil $1: 2$ )

Second incubation : 24 hours at $4^{\circ} \mathrm{C}$

Centrifugation and decantation

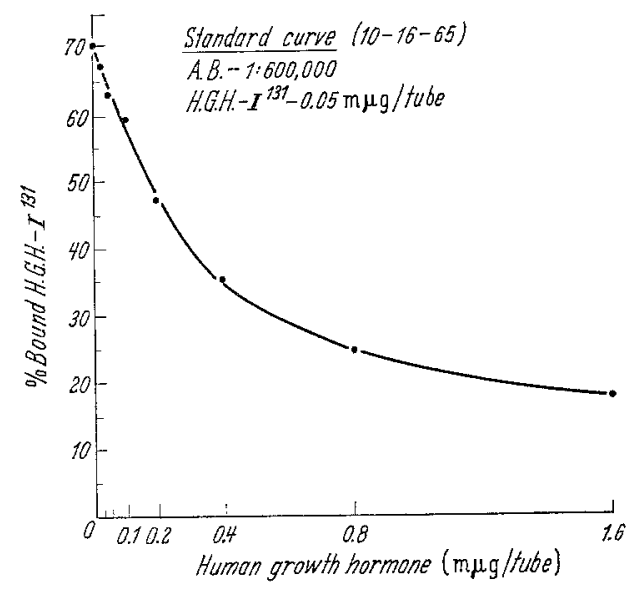

Fig. 1. A typical HGH-standard curve

\section{Results}

Equilibrium of the first reaction. Fig. 2 shows the relationship between the duration of the first reaction $\left[\mathrm{AB}+\mathrm{HGH}+\mathrm{HGH}-\mathrm{I}^{131}=\left(\mathrm{HGH}-\mathrm{AB}-\mathrm{HGH}-\mathrm{I}^{131}\right)+\right.$ $\left.\mathrm{HGH}+\mathrm{HGH}-\mathrm{I}^{131}\right]$ and the maximal precipitation of HGH-I ${ }^{131}$ bound to antibody.

Two different human sera (dil. 1:10) and one standard $(0.4 \mathrm{~m} \mu \mathrm{g})$ are shown. An equilibrium was 
reached after five days of incubation. Thus, at least a five-day incubation prior to adding the second antibody (RAGS) appears essential.

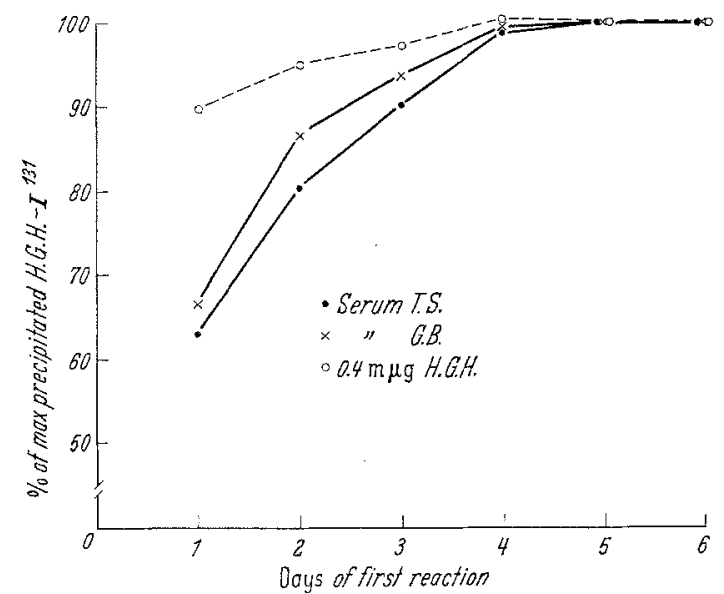

Fig. 2. Influence of time on the first reaction $[\mathrm{AB}+\mathrm{HGH}$ $\left.+\mathrm{HGH}-\mathrm{I}^{131}=\left(\mathrm{HGH}-\mathrm{AB}-\mathrm{HGH}-\mathrm{I}^{131}\right)+\mathrm{HGH}+\mathrm{HGH}-\mathrm{I}^{131}\right]$
Equilibrium of the second reaction. Fig. 3 depicts the time that is needed for complete precipitation of the guinea pig anti-HGH globulins after addition of the

Table 2. Influence of serum dilution on recovery of various quantities of added $H G H$

\begin{tabular}{|c|c|c|c|c|c|c|}
\hline$\overline{\text { Subject }}$ & $\begin{array}{l}\text { Serum } \\
\mu \mathrm{l}\end{array}$ & Serum dilution & $\begin{array}{l}\text { Serum-HGH } \\
\mu \mu \mathrm{g}\end{array}$ & $\begin{array}{l}\text { HGH added } \\
\mu \mu \mathrm{g}\end{array}$ & $\begin{array}{l}\text { HGH recovered } \\
\mu \mu \mathrm{g}\end{array}$ & Recovery in $\%$ \\
\hline M.A. & 6 & $1: 83$ & 50 & 300 & 350 & 100 \\
\hline T.S. ${ }^{1}$ & 6 & $1: 83$ & 0 & 300 & 300 & 100 \\
\hline A. G. & 6 & $1: 83$ & 106 & 300 & 331 & 82 \\
\hline C. W. ${ }^{1}$ & 6 & $1: 83$ & 231 & 300 & 550 & 103 \\
\hline \multirow[t]{2}{*}{ E.H. } & 6 & $1: 83$ & 80 & 300 & 370 & 97 \\
\hline & & & & & $\begin{array}{l}\text { Mean } \pm \\
\text { S.D. }=\end{array}$ & $96 \pm 11.0$ \\
\hline C.J. & 50 & $1: 10$ & 30 & 300 & 300 & 91 \\
\hline G.B. & 50 & $1: 10$ & 25 & 300 & 360 & 111 \\
\hline P.H. & 50 & $1: 10$ & 25 & 300 & 375 & 115 \\
\hline P.G. & 50 & $1: 10$ & 0 & 300 & 300 & 100 \\
\hline F.B. & 50 & $1: 10$ & 15 & 150 & 170 & 103 \\
\hline F.B. & 50 & $1: 10$ & 15 & 300 & 310 & 101 \\
\hline F.B. & 50 & $1: 10$ & 15 & 500 & 540 & 105 \\
\hline B. G. & 50 & $1: 10$ & 0 & 150 & 140 & 93 \\
\hline B.G. & 50 & $1: 10$ & 0 & 300 & 300 & 100 \\
\hline \multirow[t]{2}{*}{ B.G. } & 50 & $1: 10$ & 0 & 500 & 490 & 98 \\
\hline & & & & & $\begin{array}{l}\text { Mean } \pm \\
\text { S.D. = }\end{array}$ & $102 \pm 4.7$ \\
\hline K. G. & 100 & $1: 5$ & 65 & 100 & 170 & 103 \\
\hline B. F. & 100 & $1: 5$ & 75 & 100 & 188 & 107 \\
\hline \multirow[t]{2}{*}{ R.R. } & 100 & $1: 5$ & 60 & 100 & 185 & 115 \\
\hline & & & & & $\begin{array}{l}\text { Mean } \pm \\
\text { S.D. }=\end{array}$ & $108 \pm \mathbf{9 . 5}$ \\
\hline K.T. & 200 & $1: 2.5$ & 120 & 100 & 245 & 111 \\
\hline K. G. & 200 & $1: 2.5$ & 120 & 100 & 195 & 89 \\
\hline B.F. & 200 & $1: 2.5$ & 125 & 100 & 225 & 100 \\
\hline \multirow[t]{2}{*}{ R.R. } & 200 & $1: 2.5$ & 128 & 100 & 225 & 99 \\
\hline & & & & & $\begin{array}{l}\text { Mean } \pm \\
\text { S.D. }=\end{array}$ & $100 \pm 6.9$ \\
\hline R.R. & 500 & undil. & 320 & 100 & 450 & 107 \\
\hline L.D. & 500 & undil. & 270 & 100 & 400 & 108 \\
\hline B.F. & 500 & undil. & 320 & 100 & 388 & 92 \\
\hline K. G. & 500 & undil. & 305 & 100 & 420 & 104 \\
\hline \multirow[t]{2}{*}{ J.C. } & 500 & undil. & 330 & 100 & 450 & 105 \\
\hline & & & & & \multicolumn{2}{|c|}{$\begin{array}{l}\text { Mean } \pm \\
\text { S.D. }=103 \pm 8.2\end{array}$} \\
\hline
\end{tabular}


second antibody (RAGS). Shown are a standard (0.4. $\mathrm{m} \mu \mathrm{g})$ and a human serum diluted 1:10.

It can be seen that in the standard, precipitation is accomplished after two hours and in the diluted serum after eight hours. There has been no evidence in over 100 evaluations that longer than 24 hours was needed to achieve complete precipitation in the presence of diluted human serum diluted 1:10. degradation of HGH-I ${ }^{131}$ by serum, the integrity of HGH-I 131 after incubation with various serum concentrations was investigated.

The radio-labelled HGH was first incubated with the serum-buffer dilutions and antiserum diluted 1:600000 for six days at $4^{\circ} \mathrm{C}$ and then allowed to react a further eight hours with an excess amount of antiserum (0.1 ml of a 1:1000 dilution) before the

Table 3. Measured $H G H$ at various dilutions of serum in 18 male subjects expressed as $m \mu g / m l$ (corrected for dilution) and as percent of the 1:10 dilution value

\begin{tabular}{|c|c|c|c|c|c|c|c|}
\hline $\begin{array}{l}\text { Serum volume: } \\
\text { Dilution: }\end{array}$ & $\begin{array}{l}50 \mu 1 \\
1: 10\end{array}$ & $\begin{array}{l}100 \mu 1 \\
1: 5\end{array}$ & & $\begin{array}{l}200 \mu \mathrm{l} \\
1: 2.5\end{array}$ & & $\begin{array}{l}500 \mu 1 \\
\text { undiluted }\end{array}$ & \\
\hline \multicolumn{8}{|l|}{ Subject: } \\
\hline L.Sr. & 0.5 & 0.5 & $100 \%$ & 0.6 & $120 \%$ & 0.8 & $160 \%$ \\
\hline W.H. & 0.5 & 0.5 & $100^{\circ}$ & 0.5 & $100^{/ 0}$ & 0.8 & $160^{\circ}$ \\
\hline R.R. & 0.7 & 0.6 & 86 & 0.6 & 86 & 0.6 & 86 \\
\hline L. D. & 0.7 & 0.6 & 86 & 0.6 & 86 & 0.6 & 86 \\
\hline K.M. & 0.6 & 0.7 & 117 & 0.6 & 100 & 0.6 & 100 \\
\hline J.P. & 0.6 & 0.5 & 83 & 0.5 & 83 & 0.7 & 117 \\
\hline K.T. & 0.9 & 0.9 & 100 & 0.6 & 67 & 0.6 & 67 \\
\hline B.R. & 0.5 & 0.4 & 80 & 0.5 & 100 & 0.7 & 140 \\
\hline H.P. & 0.8 & 0.9 & 113 & 0.8 & 100 & 1.0 & 125 \\
\hline R.E. & 1.2 & 0.8 & 67 & 0.8 & 67 & 0.8 & 67 \\
\hline L.D. & 0.6 & 0.5 & 83 & 0.6 & 100 & 0.8 & 133 \\
\hline E.E. & 2.5 & 2.6 & 104 & 2.9 & 116 & 2.9 & 116 \\
\hline S.J. & 0.6 & 0.6 & 100 & 0.7 & 117 & 0.8 & 133 \\
\hline R.R. & 0.7 & 0.8 & 114 & 0.8 & 114 & 0.8 & 114 \\
\hline A. A. & 0.3 & 0.3 & 100 & 0.3 & 100 & 0.5 & 167 \\
\hline G.P. & 0.3 & 0.3 & 100 & 0.3 & 100 & 0.5 & 167 \\
\hline S.J. & 0.3 & 0.3 & 100 & 0.3 & 100 & 0.6 & 200 \\
\hline S.J. & 0.3 & 0.4 & 133 & 0.4 & 133 & 0.6 & 200 \\
\hline \multirow{4}{*}{$\begin{array}{l}\text { Mean: } \\
\text { S.E.M.: } \\
\text { compared with } \\
\text { the 1: } 10 \\
\text { dilution }\end{array}$} & \multirow{4}{*}{$\begin{array}{l}0.70 \pm \\
0.12\end{array}$} & \multirow{4}{*}{$\begin{array}{l}0.65 \pm \\
0.13\end{array}$} & $98.1 \% \pm$ & $0.69 \pm$ & \multirow{3}{*}{$\begin{array}{c}99.4 \% \pm \\
4.1 \%\end{array}$} & \multirow{4}{*}{$\begin{array}{l}0.82 \pm \\
0.13\end{array}$} & \multirow{3}{*}{$\begin{array}{c}129.9 \% \pm \\
9.5 \%\end{array}$} \\
\hline & & & $3.7 \%$ & 0.14 & & & \\
\hline & & & & & & & \\
\hline & & & N.S. & & N.S. & & $P<0.001$ \\
\hline
\end{tabular}

$$
\text { N.S. = not significant. }
$$

Recovery studies. Table 2 shows the results of recovery experiments in which known amounts of HGH were added to different dilutions of human sera. With $6,50,100,200$, and $500 \mu \mathrm{l}$ of serum, a mean recovery of $96 \%, 102 \%, 108 \%, 100 \%$, and $103 \%$ of the added hormone was achieved. These differences are not statistically significant.

The amount of HGH added had no effect on the percentage of recovery. As can be seen in subjects F.B. and B.G., various amounts of HGH $(150,300$, and $500 \mu \mu \mathrm{g})$ were added to the same serum dilution $(1: 10)$ and recoveries were quite similar.

Effect of Serum Dilution. Eighteen different human sera, diluted $1: 10,1: 5,1: 2.5$, and undiluted were assayed for $\mathrm{HGH}$, with a second incubation period of 24 hours. As shown in Table 3, no difference in HGH concentrations could be seen with the $1: 10$, $1: 5$, and 1:2.5 serum buffer dilutions; whereas, with undiluted serum, the mean HGH value was significantly increased to $129.9 \%$ of the value derived using the $1: 10$ dilution.

Degradation of $H G H-I^{131}$. Since the cause for this "dilution effect" seen with undiluted serum might be
Table 4. Integrity of $H G H-I^{131}$ after incubation with different serum dilutions and antiserum diluted 1:600000 for six days at $4^{\circ} \mathrm{C}^{1}$

\begin{tabular}{lllll}
\hline Serum volume: & $50 \mu \mathrm{l}$ & $100 \mu \mathrm{l}$ & $200 \mu \mathrm{l}$ & $\begin{array}{l}500 \mu \mathrm{l} \\
\text { Serum dilution: }\end{array}$ \\
\hline Namber of Sera & $1: 10$ & $1: 5$ & $1: 2.5$ & undiluted \\
\hline
\end{tabular}

HGH-I ${ }^{131}$ bound

to excess antiserum expressed as percent of the $50 \mu \mathrm{l}$ value

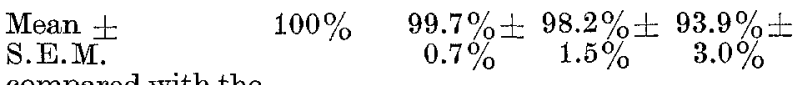
compared with the $1: 10$ dilution

N.S. $<0.05<0.001$

1 At the end of this time, excess antibody (dil. $1: 1000$ ) was added and allowed to react for eight hours before adding RAGS. The incubation with RAGS was 24 hours.

N.S. = not significant.

second antibody (RAGS) was added. In the presence of such a high concentration of antiserum intact immunoreactive $\mathrm{HGH}$ is completely bound to antibody within two to six hours. 
As seen in Table 4, $6 \%$ less HGH-I'131 is bound to the HGH-antiserum using undiluted serum than with serum diluted 1:10.

The significance of the effect of the HGH-antiserum on HGH-I ${ }^{131}$ protection is shown in Table 5, where the integrity of labelled hormone is evaluated after incuba-

Table 5. Integrity of $H G H-I^{131}$ after incubation with different sera dilutions and excess $H G H$-antiserum $(0.1 \mathrm{ml}$ dil. 1:1000) for six days at $4^{\circ} \mathrm{C}$ (second incubation 24 hours)

\begin{tabular}{lllll}
\hline Serum volume: & $\begin{array}{l}50 \mu \mathrm{l} \\
\text { Serum dilution: }\end{array}$ & $\begin{array}{l}100 \mu 1 \\
1: 10\end{array}$ & $\begin{array}{l}200 \mu 1 \\
1: 2.5\end{array}$ & $\begin{array}{l}500 \mu \mathrm{l} \\
\text { undiluted }\end{array}$ \\
\hline Number of sera & 6 & 6 & 6 & 6 \\
\hline
\end{tabular}

$\%$ HGH-I $^{131}$ bound

to excess antiserum

$\begin{array}{lcccc}\text { Mean } \pm & 100.0 \pm & 102.3 \pm & 103.6 \pm & 102.3 \pm \\ \text { S.E.M. } & 0.0 & 1.3 & 1.7 & 1.6\end{array}$

compared with the
$1: 10$ dilution N.S. N.S. N.S.

N.S. = not significant. which would indicate that some of the falsely high results obtained assaying undiluted serum might also be due to an incubation period of insufficient duration.

Other than degradation of labelled hormone and an incubation of inadequate duration, a third factor may contribute to the falsely high levels of $\mathrm{HGH}$ seen when undiluted serum is assayed. Separation of the precipitate containing the bound HGH-I ${ }^{131}$ from the free $\mathrm{HGH}-\mathrm{I}^{131}$ in the supernatant is very difficult using undiluted serum. As the precipitate often does not adequately adhere to the bottom of the test tube, it can easily slip into the supernatant tube which should contain exclusively free HGH.-I31. This inaccuracy in separation will lead to falsely high levels.

In this laboratory a 1:10 serum dilution is routinely used, and the dilution is decreased to not less than $1: 2.5$, only to detect HGH levels less than $0.25 \mathrm{~m} \mu \mathrm{g} /$ $\mathrm{ml}$ serum. It appears that incubation damage of the $\mathrm{HGH}-\mathrm{I}^{131}$ is usually in the range from $3 \%-10 \%$ in buffer and in diluted serum.

Table 6. Influence of excess RAGS and prolonged incubation on percent precipitated HGH-131

$\%$ ppt. HGH-I'131 (serum undil.; RAGS $0.1 \mathrm{ml} 1: 2$ dil.) $\%$ ppt. HGH.- ${ }^{131}$ (serum undil.; RAGS $0.3 \mathrm{ml}$ undil.)

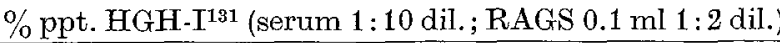
\% ppt. HGH-I ${ }^{131}$ (serum undil.; RAGS $0.1 \mathrm{ml} 1: 2$ dil.)

tion for six days with different serum dilutions in the presence of excess HGH-antiserum. It can be seen that in these experiments the degradation of $H G H-I^{131}$ was not accelerated by undiluted serum.

In order to exclude the possibilities that with undiluted serum the usual concentration of RAGS might not be sufficient to precipitate all of the bound HGH-I ${ }^{131}$, and that a six-day incubation period in the presence of undiluted serum might not be long enough for the HGH-I'131 to reach an equilibrium with the HGH-antibody, experiments were performed in which three different sera undiluted and at a $1: 10$ dilution were incubated over a six to twelve day period. Six times the usual amount of RAGS was added to one group of undiluted serum to evaluate the potency of RAGS.

As can be seen in Table 6 , the concentration of RAGS normally used $(0.1 \mathrm{ml}, 1: 2 \mathrm{dil})$ is sufficient to precipitate completely the bound HGH-I ${ }^{131}$ in undiluted serum, as the ratio:

$\%$ ppt. HGH-I'131 (RAGS $0.1 \mathrm{ml}, 1.2$ dil.)

\% ppt. HGH-I'131 (RAGS 0.3 ml, undil.)

does not decrease in any of the tested sera.

However, there is a slight decrease in the ratio:

$\%$ precipitated HGH-I ${ }^{131}$ in serum dil. $1: 10$

$\%$ precipitated $\mathrm{HGH}-\mathrm{I}^{131}$ in undil. serum

\begin{tabular}{llllll} 
Subject & 6 days & 7 days & 8 days & 11 days & 12 days \\
\hline S.S. & 1.03 & 1.00 & 1.01 & 1.02 & 1.04 \\
O.O. & - & - & - & 1.03 & $\mathbf{1 . 0 2}$ \\
Q.C. & $\mathbf{1 . 0 7}$ & $\mathbf{1 . 1 0}$ & 1.12 & 1.14 & $\mathbf{1 . 2 6}$ \\
& & & & & \\
S.S. & $\mathbf{2 . 0 0}$ & $\mathbf{1 . 9 5}$ & 1.91 & 1.79 & $\mathbf{1 . 8 3}$ \\
O.O. & - & - & 1.76 & 1.83 & $\mathbf{1 . 7 8}$ \\
Q.C. & $\mathbf{3 . 6 0}$ & $\mathbf{3 . 5 2}$ & $\mathbf{3 . 4 1}$ & 3.04 & $\mathbf{3 . 3 2}$
\end{tabular}

Sensitivity and reproducibility. An essentially linear standard curve can be derived by plotting the $\mathrm{C}_{0} / \mathrm{C}_{\mathrm{GH}}$ ratio versus the concentration of $\mathrm{HGH}$ added

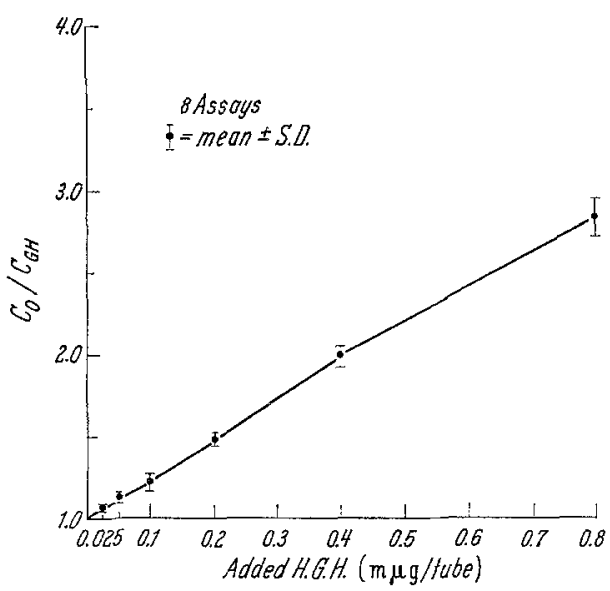

Fig. 4. Analysis of eight standard curves. $\mathrm{C}_{0} / \mathrm{C}_{\mathrm{GH}}$ ratio is plotted versus $\mathrm{HGH}$ added as standards

as standards [7]. [Co $=$ percent precipitated $\mathrm{HGH}$ $\mathrm{I}^{131}$ in buffer alone (0 standard). $\mathrm{C}_{\mathrm{GH}}=$ percent precipitated HGH-I ${ }^{131}$ in each standard.] Fig. 4 shows eight standard curves plotted in this manner. 
Linearity is found only between 0 and $0.4 \mathrm{~m} \mu \mathrm{g} \mathrm{HGH}$ / tube. With higher concentrations of $\mathrm{HGH}$, the slope decreases.

The $\mathrm{C}_{0} / \mathrm{C}_{\mathrm{GH}}$ ratios of 0 and $0.25 \mathrm{~m} \mu \mathrm{g} \mathrm{HGH} /$ tube are significantly different $(p<0.05)$. This assay is therefore sensitive enough to distinguish $0.025 \mathrm{~m} \mu \mathrm{g}$ from 0 . (In reducing the amount of HGH-I ${ }^{131}$ from 0.05 $\mathrm{m} \mu \mathrm{g}$ to $0.025 \mathrm{~m} \mu \mathrm{g}$, the slope of the $\mathrm{C}_{0} / \mathrm{C}_{\mathrm{GH}}$ plot doubles, and the assay is sensitive enough to detect 0.0125 m $\mu \mathrm{g}$ HGH.)

To achieve this degree of sensitivity, it is important to have a highly purified HGH-I ${ }^{131}$, since less pure preparations result in a decreased slope of the standard curve. Figure 5 shows two standard curves. In one,

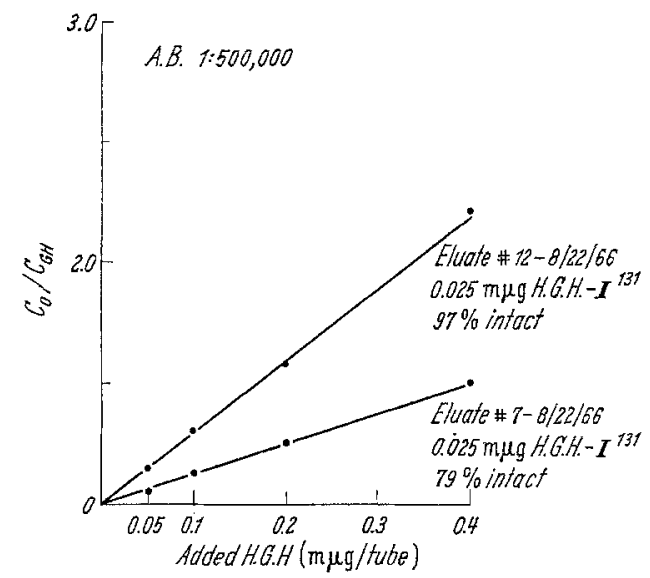

Fig. 5. Influence of integrity of HGH-I131 on sensitivity of standard curve

the HGH-I ${ }^{131}$ was initially $97 \%$ intact, in the other $79 \%$ intact. These were different eluates from the same iodination. The specific activity of the intact HGH-I ${ }^{131}$ in each eluate was assumed to be identical. The amount of intact HGH-I ${ }^{131}$ added to each standard curve was $0.025 \mathrm{~m} \mu \mathrm{g} /$ tube. After a period of 5 days incubation, the more pure eluate declined from $97 \%$ to $94 \%$ intact hormone, whereas the more damaged eluate decreased from $79 \%$ to $74 \%$ intact.

The slope of the standard curve using the more impure HGH.-I ${ }^{131}$ was about half that produced using the $97 \%$ pure hormone; mathematical correction for impurity does not make the $\mathrm{C}_{0} / \mathrm{C}_{\mathrm{Gr}}$ ratio of the curve with the damaged HGH-I ${ }^{131}$ any steeper.

In order to evaluate reproducibility, aliquots of a human serum pool were measured with each assay. In ten consecutive assays performed during the last six nonths, the HGH content of this serum was $2.8 \pm$ $0.4 \mathrm{~m} \mu \mathrm{g} / \mathrm{ml}$. (mean $\pm S . D$.

Specificity. Table 7 shows the serum HGH levels pre- and posthypophysectomy in five diabetic patients. After operation serum HGH was less than $0.5 \mathrm{~m} \mu \mathrm{g} /$ $\mathrm{ml}$ in four out of five. In one, there was still a low HGH concentration, suggesting incomplete hypophysectomy.
An intravenous insulin tolerance test $(0.1 \mathrm{U} / \mathrm{kg}$ body weight) failed to stimulate a rise of serum $\mathrm{HGH}$ in a sixth patient post-hypophysectomy.

Table 7. HGH levels in sera of five patients pre- and posthypophysectomy

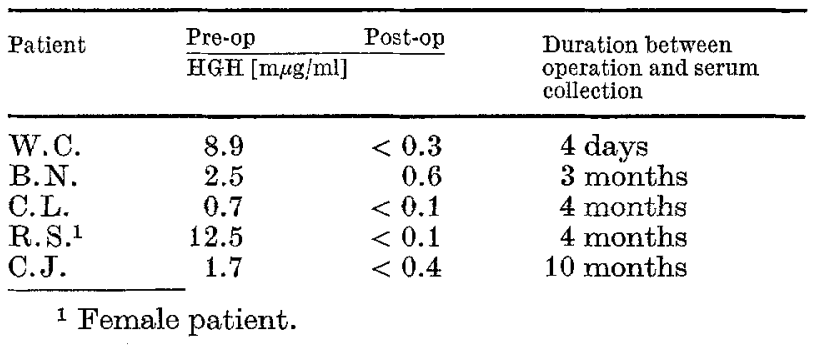

As seen in Fig. 6, there is no reaction between rat ${ }^{3}$ or porcine growth hormone ${ }^{4}$ with the guinea pig, anti human GH serum used in this assay over the range of the HGH concentration employed $(0-32 \mathrm{~m} \mu \mathrm{g})$.

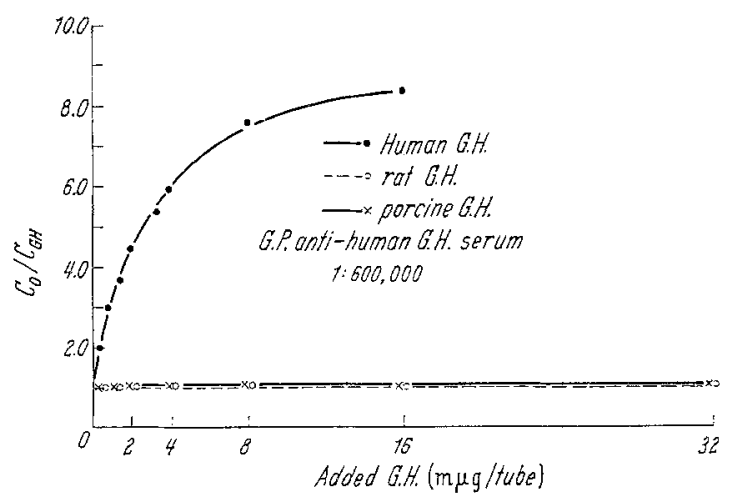

Fig. 6. Reactivity of human, rat, and porcine growth hormone with the guinea pig anti-human growth hormone serum

Sera from guinea pig, cow, mouse, rabbit, toad fish, and rhesus monkey were also tested. Of these, only monkey serum appeared to contain a material that reacted with the antibody.

Range and distribution of $H G H$ in normals and patients with acromegaly (Fig. 7). In order to assess the range and distribution of $\mathrm{HGH}$ in serum, 47 sera from healthy normal individuals ( 30 males, 17 females) and 22 sera from 15 patients with acromegaly were assayed. All subjects were fasted overnight. Blood was drawn after a recumbency of approximately 30 minutes.

In the normal males the mean serum HGH value was $0.8 \mathrm{~m} \mu \mathrm{g} / \mathrm{ml}$ ranging from 0 to $2.2 \mathrm{~m} \mu \mathrm{g} / \mathrm{ml}$ serum. Eight of the 16 normal females had serum $\mathrm{HGH}$ levels similar to the males $(0.6-1.7 \mathrm{~m} \mu \mathrm{g} / \mathrm{ml}), 8$ ranged from 4.7-15.0 m $\mu \mathrm{g} / \mathrm{ml}$, and one had a fasting $\mathrm{HGH}$

${ }^{3}$ Rat growth hormone was kindly supplied to us by Dr. R.E. Grindetiand, Ames Research Center, Moffett Field, California.

4 Porcine growth hormone was purchased from Nutritional Biochemicals Corporation, Cleveland, Ohio. 
level of $57 \mathrm{~m} \mu \mathrm{g} / \mathrm{ml}$. The mean GH concentration in the acromegalics was $31.2 \mathrm{~m} \mu \mathrm{g} / \mathrm{ml}$, ranging from $8.0-103.0 \mathrm{~m} \mu \mathrm{g} / \mathrm{ml}$ serum.

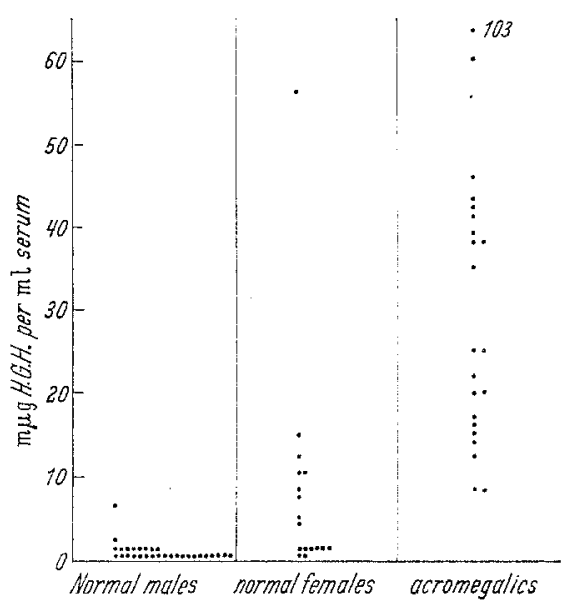

Fig. 7. Distribution of serum $\mathrm{HGH}$ in normal males and females and in patients with acromegaly

Higher fasting levels of HGH in females have been reported earlier [19, 18]. Frantz found that this sex difference disappears under basal conditions, i.e., when the blood is taken at the moment of awakening $[3]$.
HGH levels during i.v. tolbutamide tolerance test. Serum HGH concentrations in 11 normal males were assayed during a rapid $i . v$. tolbutamide tolerance test $(1.0 \mathrm{~g}$ infused in $3 \mathrm{~min})$.

As seen in Table 8, there was a rise in the HGH levels of all eleven subjects.

In seven out of the eleven subjects, the serum HGH started rising during the 20 minutes following the glucose nadir. In two persons the $\mathrm{HGH}$ rise occurred 40 minutes, in one 60 minutes, and in the last subject 70 minutes after the glucose had reached its lowest point. In another subject in whom the blood glucose was kept relatively constant $(67-78 \mathrm{mg} \%$ ) by continuous infusion of glucose, there was no rise in serum $\mathrm{HGH}$ after tolbutamide. This indicates that only the hypoglycemia and not hyperinsulinemia or tolbutamide itself is responsible for the rise in serum HGH after intravenous tolbutamide infusion.

\section{Discussion}

Basal serum HGH levels, i.e., the HGH concentration within two minutes of first awakening in the morning, following an overnight fast and before the occurrence of any significant activity [3], have been found by several investigators $[5,10]$ to be less than $1.0 \mathrm{~m} \mu \mathrm{g} / \mathrm{ml}$ serum or plasma. Using a similarly

Table 8. HGH concentrations $(m \mu g / m l)$ in eleven normal male subjects during rapid $i . v$. tolbutamide tolerance test ${ }^{1}$ $(1.0 \mathrm{~g}$ in $20 \mathrm{ml}$ saline injected within $3 \mathrm{~min})$

\begin{tabular}{|c|c|c|c|c|c|c|c|c|c|c|c|}
\hline \multirow[t]{2}{*}{ Subject } & \multicolumn{11}{|c|}{ Minutes } \\
\hline & 0 & 5 & 10 & 20 & 30 & 40 & 50 & 60 & 90 & 120 & 180 \\
\hline B.F. & $\begin{array}{l}(75) \\
1.5\end{array}$ & $\begin{array}{l}(70) \\
1.8\end{array}$ & $\begin{array}{l}(67) \\
1.4\end{array}$ & $\begin{array}{l}(47) \\
1.0\end{array}$ & $\begin{array}{l}(30) \\
1.5\end{array}$ & $\begin{array}{l}(37) \\
3.2\end{array}$ & $\begin{array}{l}(51) \\
18.7\end{array}$ & $\begin{array}{l}(52) \\
23.5\end{array}$ & $\begin{array}{l}(58) \\
16.0\end{array}$ & $\begin{array}{l}(61) \\
6.2\end{array}$ & $\begin{array}{l}(67) \\
1.9\end{array}$ \\
\hline B.R. & $\begin{array}{l}(69) \\
1.1\end{array}$ & $\begin{array}{l}(65) \\
1.6\end{array}$ & $\begin{array}{l}(57) \\
1.4\end{array}$ & $\begin{array}{l}(44) \\
0.5\end{array}$ & $\begin{array}{l}(29) \\
0.7\end{array}$ & $\begin{array}{l}(35) \\
0.9\end{array}$ & $\begin{array}{l}(49) \\
9.1\end{array}$ & $\begin{array}{l}(51) \\
18.0\end{array}$ & $\begin{array}{l}(59) \\
6.9\end{array}$ & $\begin{array}{l}(63) \\
2.4\end{array}$ & $\begin{array}{l}(67) \\
1.2\end{array}$ \\
\hline R.R. & $\begin{array}{l}(71) \\
1.8\end{array}$ & $\begin{array}{l}(65) \\
1.3\end{array}$ & $\begin{array}{l}(61) \\
1.5\end{array}$ & $\begin{array}{l}(54) \\
1.5\end{array}$ & $\begin{array}{l}(44) \\
1.4\end{array}$ & $\begin{array}{l}(40) \\
1.6\end{array}$ & $\begin{array}{l}(50) \\
2.5\end{array}$ & $\begin{array}{l}(52) \\
4.5\end{array}$ & $\begin{array}{l}(56) \\
2.4\end{array}$ & $\begin{array}{l}(60) \\
1.2\end{array}$ & $\begin{array}{l}(64) \\
1.5\end{array}$ \\
\hline S.J. & $\begin{array}{l}(83) \\
0.4\end{array}$ & $\begin{array}{l}(77) \\
0.4\end{array}$ & $\begin{array}{l}(71) \\
0.4\end{array}$ & $\begin{array}{l}(51) \\
0.4\end{array}$ & $\begin{array}{l}(36) \\
0.4\end{array}$ & $\begin{array}{l}(33) \\
0.5\end{array}$ & $\begin{array}{l}(34) \\
0.5\end{array}$ & $\begin{array}{l}(47) \\
6.0\end{array}$ & $\begin{array}{l}(57) \\
32.5\end{array}$ & $\begin{array}{l}(62) \\
8.5\end{array}$ & $\begin{array}{l}(69) \\
2.2\end{array}$ \\
\hline W.G. & $\begin{array}{l}(77) \\
0.5\end{array}$ & $\begin{array}{l}(73) \\
0.4\end{array}$ & $\begin{array}{l}(70) \\
0.4\end{array}$ & $\begin{array}{l}(59) \\
0.4\end{array}$ & $\begin{array}{l}(52) \\
0.4\end{array}$ & $\begin{array}{l}(50) \\
0.9\end{array}$ & $\begin{array}{l}(53) \\
0.4\end{array}$ & $\begin{array}{l}(59) \\
3.7\end{array}$ & $\begin{array}{l}(65) \\
14.8\end{array}$ & $\begin{array}{l}(68) \\
6.2\end{array}$ & $\begin{array}{l}(70) \\
1.5\end{array}$ \\
\hline L. F. & $\begin{array}{l}(78) \\
1.0\end{array}$ & $\begin{array}{l}(75) \\
0.8\end{array}$ & $\begin{array}{l}(72) \\
1.0\end{array}$ & $\begin{array}{l}(68) \\
0.8\end{array}$ & $\begin{array}{l}(64) \\
1.0\end{array}$ & $\begin{array}{l}(60) \\
1.0\end{array}$ & $\begin{array}{l}(58) \\
0.8\end{array}$ & $\begin{array}{l}(57) \\
1.0\end{array}$ & $\begin{array}{l}(66) \\
10.2\end{array}$ & $\begin{array}{l}(68) \\
9.6\end{array}$ & $\begin{array}{l}(73) \\
2.2\end{array}$ \\
\hline G.M. & $\begin{array}{l}(76) \\
1.5\end{array}$ & $\begin{array}{l}(74) \\
1.4\end{array}$ & $\begin{array}{l}(68) \\
1.5\end{array}$ & $\begin{array}{l}(58) \\
1.2\end{array}$ & $\begin{array}{l}(52) \\
1.2\end{array}$ & $\begin{array}{l}(46) \\
1.1\end{array}$ & $\begin{array}{l}(52) \\
8.6\end{array}$ & $\begin{array}{l}(56) \\
15.0\end{array}$ & $\begin{array}{l}(62) \\
10.9\end{array}$ & $\begin{array}{l}(64) \\
6.6\end{array}$ & $\begin{array}{l}(74) \\
2.3\end{array}$ \\
\hline B. G. & $\begin{array}{l}(73) \\
0.5\end{array}$ & $\begin{array}{l}(71) \\
0.5\end{array}$ & $\begin{array}{l}(65) \\
0.6\end{array}$ & $\begin{array}{l}(55) \\
0.9\end{array}$ & $\begin{array}{l}(46) \\
0.8\end{array}$ & $\begin{array}{l}(43) \\
0.6\end{array}$ & $\begin{array}{l}(41) \\
0.6\end{array}$ & $\begin{array}{l}(44) \\
0.8\end{array}$ & $\begin{array}{l}(57) \\
18.0\end{array}$ & $\begin{array}{l}(59) \\
7.9\end{array}$ & $\begin{array}{l}(61) \\
1.2\end{array}$ \\
\hline G.H. & $\begin{array}{l}(73) \\
6.5\end{array}$ & $\begin{array}{l}(73) \\
7.9\end{array}$ & $\begin{array}{l}(67) \\
6.2\end{array}$ & $\begin{array}{l}(53) \\
6.0\end{array}$ & $\begin{array}{l}(44) \\
4.0\end{array}$ & $\begin{array}{l}(44) \\
2.4\end{array}$ & $\begin{array}{l}(44) \\
2.1\end{array}$ & $\begin{array}{l}(47) \\
1.9\end{array}$ & $\begin{array}{l}(61) \\
18.7\end{array}$ & $\begin{array}{c}(63) \\
13.6\end{array}$ & $\begin{array}{l}(65) \\
3.1\end{array}$ \\
\hline G.R. & $\begin{array}{l}(72) \\
8.2\end{array}$ & $\begin{array}{l}(70) \\
4.7\end{array}$ & $\begin{array}{l}(67) \\
3.5\end{array}$ & $\begin{array}{l}(59) \\
2.1\end{array}$ & $\begin{array}{l}(53) \\
1.6\end{array}$ & $\begin{array}{l}(50) \\
1.4\end{array}$ & - & $\begin{array}{l}(53) \\
7.4\end{array}$ & $\begin{array}{l}(65) \\
19.0\end{array}$ & $\begin{array}{l}(68) \\
7.4\end{array}$ & $\begin{array}{l}(68) \\
3.2\end{array}$ \\
\hline J.C. & $\begin{array}{l}(87) \\
0.5\end{array}$ & $\begin{array}{l}(83) \\
0.5\end{array}$ & $\begin{array}{l}(77) \\
0.5\end{array}$ & $\begin{array}{l}(65) \\
0.5\end{array}$ & $\begin{array}{l}(58) \\
0.5\end{array}$ & $\begin{array}{l}(56) \\
0.6\end{array}$ & $\begin{array}{l}(54) \\
0.6\end{array}$ & $\begin{array}{l}(61) \\
1.1\end{array}$ & $\begin{array}{l}(68) \\
0.5\end{array}$ & $\begin{array}{l}(79) \\
10.6\end{array}$ & $\begin{array}{l}(80) \\
5.5\end{array}$ \\
\hline
\end{tabular}

${ }^{I}$ In brackets, glucose concentrations in $\mathrm{mg} \%$, determined by the ferricyanide method of Hoffman modified for use with Technicon Auto Analyzer [8]. 
highly purified $\mathrm{HGH}$ as reference standard, we have confirmed the results of these authors using, however, a double antibody immunoassay technique.

In order to study secretion mechanisms of $\mathrm{HGH}$, it is desirable to have an assay sensitive enough to measure low basal levels and changes of concentration which often do not exceed a few $\mathrm{m} \mu \mathrm{g} / \mathrm{ml}$ serum. For instance, a tenfold rise of $\mathrm{HGH}$ from 0.2 to $2.0 \mathrm{~m} \mu \mathrm{g} /$ $\mathrm{ml}$ following a stimulus would be undetectable by an assay with a sensitivity of only $2.0 \mathrm{~m} \mu \mathrm{g} / \mathrm{ml}$. The sensitivity of the assay depends mainly on two factors. One is a tracer hormone of high purity; at least 90\% of the labelled HGH should be intact. Another is a concentration of antibody which binds from $55 \%$ to $65 \%$ of the added tracer in buffer alone. This gives optimal results, i.e., the steepest possible slope for the standard curve. The sensitivity of this double-antibody-assay is $0.0125 \mathrm{~m} \mu \mathrm{g}$, and as $0.2 \mathrm{ml}$ of serum can be assayed, $0.0625 \mathrm{~m} \mu \mathrm{g}$ of $\mathrm{HGH}$ in $1.0 \mathrm{ml}$ of serum can be detected.

In order to obtain comparable values for serum HGH employing this double antibody technique, the initial incubation of serum, guinea pig antiserum, and HGH-I ${ }^{131}$ must proceed for at least five days. Only after that period of time is an equilibrium reached. Since the reference standards achieve this equilibrium earlier than serum, shorter incubation time would lead to erroneously high results. Routinely, the first incubation period lasts six days. In several time studies including 13 different sera, only one serum was found in which equilibrium was not reached after six days. Cerrast et. al. [2], in a recent publication, saw no equilibrium even after incubations as long as 20 days. We have no explanation for their findings other than the major differences in the assay techniques used by those authors in comparison with ours nor for the single serum that did not reach equilibrium in the present studies.

Recoveries with various dilutions of serum and with undiluted serum appear quite acceptable. There seems to be no inhibitor in serum which interferes with the second reaction as described by MorGan et al. [15] for the double antibody assay of insulin in plasma. This inhibitor seems to delay the rate of precipitation by the RAGS. However, the relatively long second incubation period employed in this assay allowing for complete equilibration may account for the absence of the inhibitor effect [17].

Between two extremes, i. e. no HGH-antiserum and excess HGH-antiserum, are the conditions under which the assay is performed. It is apparent that with the appropriate amount of HGH-antiserum and with at least 90 percent intact $\mathrm{HGH}-\mathrm{I}^{131}$ added for the assay procedure, approximately 50 percent or more of the HGH-I ${ }^{131}$ has bound to antibody within two days if the total amount of unlabelled HGH (standard or unknown) is small allowing a relatively large proportion of the HGH-I ${ }^{131}$ to bind to the antibody.

Binding to the antibody protects this labelled hormone from degradation; consequently, the greater proportion of bound hormone reduces the amount of free HGH-I ${ }^{131}$ in the supernatant available for destruction. It appears, therefore, that an appropriate serum dilution, be it small or large, that will allow for a high percentage of precipitable HGH-I ${ }^{131}$ is the most critical factor in the assay design and not merely the absolute dilution of the unknown serum. In this assay as described, only those sera containing less than $0.25 \mathrm{~m} \mu \mathrm{g} / \mathrm{ml}$ need to be assayed at less than 1:10 dilution.

Except for a cross-reacting material that JosImoVICH and MACLAREN [11] found in serum from pregnant women (human placental lactogen), the $\mathrm{HGH}$ radioimmunoassay appears to be specific for HGH. However, the most purified HGH preparations contain considerable prolactin activities; and it is still not clear whether human prolactin and growth hormone activities are properties of the same molecule [12]. Therefore, it cannot be excluded that in some instances the assay measures prolactin, as well as HGH. This could account for the higher values in some women, since it is known that estrogens increase prolactin secretion [13].

The i.v. tolbutamide test appears to be a good provocative test for studies of $\mathrm{HGH}$ secretion [10]. Changes in serum $\mathrm{HGH}$ concentration after infusion of tolbutamide are not due to unspecific factors as, with very few exceptions, no change in serum HGH occurs during the first two hours after $i . v$. infusion of glucose in men [1]. Changes in blood glucose are similar in timing to those seen during the $i . v$. insulin tolerance test.

Because of the less pronounced decrease of the blood sugar after $i . v$. tolbutamide in comparison with $i . v$. insulin, many of the risks of the $i . v$. insulin tolerance test are avoided. This is of particular interest in patients with hypothalamic or pituitary hypofunction because of the known hypersensitivity of these persons to insulin. Furthermore, changes in endogenous insulin can also be performed without interference with exogenous insulin.

\section{References}

[1] Boden, G., J. Somldner, J. Stemnke and G.W. THORN: Serum human growth hormone (HGH) response to IV glucose: Diagnosis of acromegaly in females and males. Submitted for publication.

[2] Cerasi, E., L. Della Casa, R. Luft and A. Roovete: Determination of human growth hormone (HGH) in plasma by a double antibody radioimmunoassay. Acta Endocr. 53, 101-120 (1966).

[3] Frantz, A.G., and M.T. RabKin : Effects of estrogen and sex difference on secretion of human growth hormone. J. clin. Endoc. 25, 1470-1480 (1965).

[4] GLTCK, S.M., J. Roth, R. S. Yalow and S.A. Benson: Immunoassay of human growth hormone in plasma. Nature 199, 784-787 (1963).

[5] - - - - The regulation of growth hormone secretion. Recent Progr. Hormone Res. 21, 241 - 283 (1965). 
[6] Greenwood, F.C., W.M. Hunter and A. Kuopper: Assay of human growth hormone in pregnancy at parturition and in lactation. Brit. Med. J. 1964 I, $22-24$.

[7] Hales, C.N., and P.J. Randle: Immunoassay of insulin with insulin-antibody precipitate. Biochem. J. 88, 137-146 (1963).

[8] Hoffmar, W.S.: A rapid photoelectric method for determination of glucose in blood and urine. J. biol. Chem. 120, $51-55$ (1937).

[9] Hunter, W.M., and F.C. Grennwood: A radioimmuno-electrophoretic assay for human growth hormone. Biochem. J. 91, 43-56 (1964).

[10] - - Studies on the secretion of human-pituitarygrowth hormone. Brit. med. J. 1964 I, 804-807.

[11] Josmovich, J.B., and J.A. MacLarein: Presence in the human placenta and term serum of a highly lactogenic substance immunologically related to pituitary growth hormone. Endocrinology 71, 209220 (1965).

[12] LI, C.H.: Discussion on prolactin. Ciba Found. Colloq. Endocrinol. 14, 360-362 (1962).

[13] Meites, J., and C.S. Nicolu: Adenohypophysis: Prolactin. Ann. Rev. Physiol. 28, 57-88 (1966).

[14] Morgan, C.R., and A. Lazarow: Immunoassay of insulin using a two-antibody system. Proc. Soc. exp. Biol. 110, 29-32 (1963).

[15] -, R.L. Sorenson and A. Lazarow : Further studies of an inhibitor of the two-antibody immunoassay system. Diabetes 13, 579-584 (1964).

[16] Schalch, D.S., and M.L. PARKer : A sensitive double antibody immunoassay for human growth hormone in plasma. Nature 203, 1141-1142 (1964).

[17] SOELDNER, J.S., and D. Stone: Critical variables in the radio immunoassay of serum insulin using the double antibody technic. Diabetes 14, 771 - 779 (1965).

[18] UNGER, R.H.: High growth hormone levels in diabetic ketoacidosis: J. Amer. med. Ass. 191, 945-947 (1965).

[19] -, A.M. Eisentraaut, L.L. Madison and M.D. SIPERSTEIr: Fasting levels of growth hormone in men and women. Nature 205, 804-805 (1965).

[20] YaLow, R.S., and S.A. Berson: Immunoassay of endogenous plasma insulin in man. J. clin. Invest. 39, $1157-1175(1960)$.

Guenther Boden

Joslin Research Laboratory

170 Pilgrim Road

Boston, Mass. 02215, U.S.A. 